\title{
Creditor protection, information sharing and credit for small and medium-sized enterprises: cross-country evidence
}

\author{
Arturo Galindo and Alejandro Micco
}

\begin{abstract}
Using World Business Environment Survey results for firms in 61 countries, together with country dummies that allow us to deal with observed and unobserved country-specific components, as well as with partial endogeneity, we explore the roles played by creditor protection (e.g. the enforcement of credit contracts) and by the development of credit information mechanisms, such as credit registries, in determining the availability of bank credit for small and medium-sized enterprises (SMEs). We find that better creditor protection and the development of information-sharing mechanisms narrow the financing gap between small and large firms. Countries with poor creditor protection can offset this shortcoming by implementing credit information mechanisms.
\end{abstract}

\section{Keywords}

Small enterprises, medium-sized enterprises, business financing, credit, credit controls, access to information, econometric models

JEL classification

G30, G10, K40

Authors

Arturo Galindo is Chief of the Strategy Development Division of the Inter-American Development Bank (IDB). ajgalindo@gmail.com

Alejandro Micco is Vice Minister of Finance of Chile. amicco@hacienda.gov.cl 


\section{Introduction}

A large body of literature emphasizes the positive influence that the development of a country's financial sector has on the level and rate of growth of its per capita income. Credit supplied by the banking sector is the most important funding source for firms and households in most countries, in particular developing ones. Unfortunately, bank credit is more expensive and in more limited supply for small and medium-sized enterprises (SMEs) than it is for large firms, which also have a wider range of other financial options. Using comparable cross-section country data on commercial bank credit from 61 countries, while controlling for country fixed effects, we look at the importance of: (i) the role of the legal system in requiring and enforcing loan repayment and the superiority of the common law system in this regard; and (ii) the different types of institutional protection, such as credit bureaux, which can correct the information asymmetries that deter lenders, and their role in shaping access to bank credit. We find that the share of total financing this is obtained from banks is around 30 percentage points greater for SMEs in countries with common law regimes than in those with civil law systems. The presence of a credit registry also increases the level of bank credit for SMEs relative to large firms by around 30 percentage points. Furthermore, our results suggest that creditor rights and the presence of a credit registry are substitutes for one another. Consequently, credit registries have a strong impact on credit in countries with low levels of legal protection (see table 3).

In financial markets, information asymmetries and a lack of contract enforceability constitute a critical barrier to access to finance. However, the financial structure is not independent of firm size. In fact, firm size is a key variable in the analysis of financial restrictions (Beck, Demirgüç-Kunt and Maksimovic, 2005). Large and small firms do not have equal opportunities to access external sources of finance.

Problems of agency costs, information asymmetries and fixed transaction costs result in financial market imperfections. The firms that are typically the most affected by these imperfections are small firms, as their internal information can be rather opaque or, at the least, is not as publicly available as is the case in their larger counterparts. Small firms seeking small loans face higher transaction costs and higher risk premiums because their financial status is less transparent and they have less collateral to offer (Beck and Demirgüç-Kunt, 2006). Similar results have been found by Beck, Demirgüç-Kunt and Maksimovic (2005), Beck and others (2006), and Schiffer and Weder (2001). The latter study also confirms that small firms are confronted with higher barriers to growth.

Recent corporate finance literature has emphasized the role played by financial development and legal protection for outside creditors in terms of corporate performance. One of the crucial implications of these findings is that underdeveloped financial systems may constrain the ability of firms to invest. In these studies, there are two broad views regarding credit to the private sector across economies (Djankov, McLiesh and Shleifer, 2007). The first one stresses the power of creditors. When banks have the ability to force repayment, confiscate collateral or even gain control of the firm, they provide more credit (Townsend, 1979). The second view stresses the importance of information in lending activity. There is a large body of literature that explores the problems posed by moral hazard and adverse selection in financing activity and explains how they reduce access to credit. ${ }^{1}$ The more that lenders know about borrowers, their credit history and their total level of debt, the more these problems are mitigated.

The literature on credit markets has identified different ways in which a lender can overcome repayment issues; the most notable of them is the use of collateral. The provision of collateral can serve as a mechanism for mitigating information asymmetries and thus solving credit rationing problems. If the interest rate does not fulfil its role efficiently due to indirect effects on the average quality of credit

1 See Stiglitz and Weiss (1981) and Freixas and Rochet (2008) for a description of the literature. 
portfolios, banks can rely on collateral. By taking into account the possibility of pairing collateral with a given interest rate, equilibrium can be achieved without credit rationing.

However, not all loans can readily be backed up with collateral. The collateralization of loans is often problematic for certain types of firms (i.e. new firms, micro-entrepreneurs and SMEs) that often do not have enough fixed assets to offer as collateral. Collateralization is also problematic in countries in which creditor rights are not well protected and where the process of seizing collateral is costly and takes a long time. In this context, the institutional framework for the legal protection of creditors has a particularly strong influence on access to credit, especially for SMEs.

For a review of the importance of collateral in terms of credit contracts and the institutions that support the use of collateral, see La Porta and others (1997 and 1998) and Schiantarelli (1996). Two main findings emerge from this literature: (i) external finance is more costly than internal finance unless loans are fully collateralized; and (ii) the premium on external finance is an inverse function of a borrower's net worth (liquid assets plus the collateral value of illiquid assets). Credit bureaux and/ or credit registries can also alleviate the asymmetry of information between lenders and borrowers. ${ }^{2}$ The loan and payment history of borrowers reduces information asymmetries and allows lenders to determine their clients' repayment potential. This mechanism creates a different form of collateral -reputation collateral - that banks can use to screen potential borrowers. ${ }^{3}$ Credit reporting can therefore be an extremely valuable source of enhanced, fact-based credit risk assessment for creditors and, as such, can facilitate access to financing for SMEs as well as other enterprises. However, the difference lies in the fact that, while credit data and other relevant information on large corporations are generally broadly available, this is usually not the case of information on SMEs.

Facilitating the flow of such credit-related data and other relevant financial information on SMEs helps to alleviate their financing constraints. Ensuring that creditors have ready access to accurate, meaningful and sufficient information on SMEs in a systematic and timely manner enhances their ability to assess SME creditworthiness and hence increases SME access to credit financing. Using a survey on banks, Beck, Demirgüç-Kunt and Martínez Pería (2008) confirm the importance of the availability of sufficient credit history data on SMEs: $70 \%$ of developing-country banks and $44 \%$ of developedcountry banks that responded to the survey stated that the existence of a credit bureau in their country facilitated SME lending.

The purpose of this study is to analyse the importance of creditors' legal rights and borrowers' information-sharing mechanisms in accounting for the variations in access to bank credit of firms of different sizes across countries. In the presence of inefficient legal protection and a lack of borrower information, banks have to monitor their borrowers more closely. Given fixed monitoring costs, lending to SMEs becomes less profitable vis-à-vis lending to large firms and, therefore, the lack of legal protection and information can be expected to disproportionately increase financial restrictions for SMEs.

Most cross-section studies fail to control for the possible endogeneity of creditor protection and information institutions (credit bureaux). It is likely, for example, that, following an increase in bank lending, countries will tend to develop stricter creditor protection laws and credit registries. Consequently, a simple cross-country regression between bank lending and creditor protection/credit bureaux is likely to overestimate the causal effect of these two factors on corporate lending.

To avoid this endogeneity problem, we used dummy countries to run a difference-in-difference Tobit model at the firm level to compare bank credit to SMEs with bank credit to large firms across

2 Credit registries may be private or public, and their practices vary in terms of the information that they collect, whether on positive or negative credit behaviour, or both.

3 See Pagano and Jappelli (1993), Padilla and Pagano (1997) and Bennardo, Pagano and Piccolo (2009) for theoretical papers on the alleviation of information asymmetry. 
countries with different levels of legal protection and information institutions. This methodology allows us to control for any country-omitted variable and for the endogeneity problem just described. To assess the importance of creditors' legal rights, we use the "creditor rights" index first proposed by La Porta and others (1997 and 1998). The index measures the legal rights of creditors vis-à-vis defaulting debtors in different jurisdictions. To assess the importance of information in terms of credit, we use the presence and coverage of credit bureaux. The role of credit bureaux is to collect, distribute and, in many cases, analyse information on a borrower's behaviour that has been gleaned from a variety of sources in order to enable creditors to screen potential clients. As noted earlier, the information compiled by private or public credit registries, whether on positive or negative credit behaviour, or both, varies.

We find that the development of credit information mechanisms - as measured, among other metrics, by the population coverage of credit bureaux or public credit registries - is an important factor in narrowing the gap between small and large firms in terms of their access to bank finance. A one-standard-deviation increase in the coverage of credit-reporting institutions reduces the financing gap for small firms by nearly half. In countries where credit registries cover less than $1 \%$ of the total population, the share of investment in small firms financed by bank credit corresponds to only $40 \%$ of the share of investment in large enterprises that is financed by banks. This figure rises to $63 \%$ in countries where credit registries cover more than 1\% of the total population (see figure 1A).

We also find that the extent of credit constraints on smaller firms depends on the quality of the regulatory framework, suggesting that, in countries where creditor rights are protected (and enforced), smaller firms have greater access to bank credit for investment purposes. In our sample, this effect is large. In common-law countries (where creditor protection is high), the share of investment financed with bank credit in small firms corresponds to $75 \%$ of the share financed in large enterprises. This percentage falls to $50 \%$ in non-common-law countries (see figure $1 \mathrm{~B}$ ).

The rest of this study is organized as follows. In section II, we briefly describe the available empirical literature on the impact of credit bureaux and legal protection on credit markets. Section III describes the econometric methodology that has been used. Section IV presents the data and some unconditional results. Sections V and VI present our baselines and robustness results. Section VII concludes our findings.

\section{A review of the empirical evidence}

Empirical evidence at the aggregate country level supports the idea that enforcing creditors' legal rights and information-sharing via credit bureaux or public credit registries have a positive impact on credit markets in terms of access to credit, interest rates and default rates. ${ }^{4}$

Using country-level data on 129 different jurisdictions for 1978-2003, Djankov, McLiesh and Shleifer (2007) find that both creditor protection and information sharing have a positive correlation with credit relative to GDP. Although both types of institutions play a complementary role in fostering private credit, these authors find that the effectiveness of each of these institutions varies across countries, depending on the type of legal system that is in place. While legal protection of creditors is associated with common law traditions, credit bureaux and public credit registries are more effective in civil-law countries.

Jappelli and Pagano (2002) provide evidence similar to the evidence presented by Djankov, McLiesh and Shleifer (2007), although for a much smaller sample of countries. Similarly, in a cross-

4 Galindo and Micco (2007) present evidence that financial development also has an impact on credit volatility; Feldmann (2013) provides evidence which indicates that financial development has an impact on firms' labour decisions as well. 
country study, Warnock and Warnock (2008) show that the development of mortgage credit markets is positively correlated with the development of credit bureaux. ${ }^{5}$

Empirical evidence at the firm level is scarcer but is necessary in order to assess the impact of information sharing on credit access that is conditional on the characteristics of the firms that are seeking loans. Galindo and Miller (2001) analysed cross-sectional balance sheet data (mostly from large, listed firms) and found that information sharing reduces credit constraints, particularly for small and young firms. They estimated investment equations and found that investment was less sensitive to a firm's cash flow - a metric traditionally used to assess credit constraints - in countries with more developed information-sharing institutions. As mentioned earlier, these cross-country estimates are likely to be upward biased due to endogeneity.

Love and Mylenko (2003) use World Business Environment Survey data to test the impact of the presence of a credit bureau on the perception of firms facing credit constraints and on an increased probability of a firm relying on bank lending. They find that the existence of a private credit bureau is associated with situations in which few firms report that they are financially constrained and more companies report that they rely on bank credit. This last of these results is stronger for small and medium-sized firms.

There is little evidence at the firm level regarding the impact and interaction of the presence of credit bureaux and the existence of legal creditor protection policies. Brown, Jappelli and Pagano (2009) use cross-sectional estimates and a panel of information on transition countries in Eastern Europe to assess the role of information sharing in countries with weak corporate laws and creditor rights. They find that, on aggregate, information sharing is associated with more abundant and cheaper credit. At the firm level, based on cross-sectional data, they find that information sharing and transparency are substitutes for one another in improving credit access. This is the first study to include panel data in an assessment of the impact of information sharing, but the results are inconclusive regarding the relationship between credit bureaux, creditors' legal protection and access to credit for different types of firms (in terms of size and transparency). This is partly because their sample does not provide crosscountry variation with regard to creditors' legal protection. In addition, these authors do not control for countries' individual time trends during a period when transition economies were undergoing many different types of changes.

We use a difference-in-difference approach to analyse the impact of creditor protection and information sharing on the share of investment financed with bank credit. Using a similar approach and cross-sectional data from the Business Environment Surveys of the World Bank, Galindo and Micco (2005) show that weak legal protection has a stronger negative impact on SMEs. ${ }^{6}$ In line with Djankov, McLiesh and Shleifer (2007), they find that the gap in credit access between SMEs and large firms is bigger in non-common-law countries.

None of these previous studies looked at the impact or interaction of credit bureaux and legal creditor protection policies using a difference-in-difference methodology.

\section{Econometric methods}

Our hypothesis implies that, compared to large firms, SMEs should have greater relative access to credit in countries where the legal rights of creditors are strong and information sharing is more developed. The dependent variable in our study is the share of financing that comes from banks. Given

\footnotetext{
5 Other authors emphasize the impact of credit bureaux on private credit and find that credit reporting helps lenders to reduce default rates. Examples include IDB (2004), Powell and others (2004), Barron and Staten (2003) and Kallberg and Udell (2003).

6 This is an earlier working paper which focuses only on creditor protection.
} 
that this variable is restricted to between 0 and 100, we use the Tobit censored regression model and introduce dummy countries to capture country fixed effects. ${ }^{7}$ Although Greene (2004) shows that the location coefficients in the Tobit model, unlike those in the probit and logit models, are unaffected by the "incidental parameters problem", we use ordinary least squares (OLS) estimations for robustness. In order to control for relevant firm-level characteristics that may affect access to bank credit, we estimate empirical models at the firm level. For that purpose, we control for variables commonly used in the literature, such as the firm's export orientation or lack thereof, the firm's ownership structure (whether it is government-owned or foreign-owned), and use sector dummies which indicate the area in which the firm operates. To capture the difference in the financing gap associated with different levels of information sharing and creditor protection, we include size dummies (Small and Medium) and interactions between these dummies and our measures of information sharing and creditor rights.

We exploit country/firm variations by estimating the following Tobit model:

$$
C_{i j c}=\left\{\begin{array}{lll}
C_{i j c}^{*} & \text { if } & 0<C_{i j c}^{*}<1 \\
0 & \text { if } & C_{i j c}^{*} \leq 0 \\
100 & \text { if } & C_{i j c}^{*} \geq 1
\end{array}\right.
$$

Where $\mathrm{C}^{\star}$ is the following latent variable:

$$
\begin{aligned}
& C_{i j c}=\alpha_{j}+\alpha_{c}+\delta X_{i j c}+\delta_{1} \text { Small }_{i j c}+\delta_{2} \text { Medium }_{i j c}+\delta_{3} \operatorname{Small}_{i j c} * \operatorname{Inf}_{c} \\
& +\delta_{4} \text { Medium }_{i j c} * \operatorname{Inf}_{c}+\delta_{5} \text { Small }_{i j c} * C R_{c}+\delta_{6} \text { Medium }_{i j c} * C R_{c}+\varepsilon_{i j c}
\end{aligned}
$$

where $C_{j j c}$ denotes the share of investment financed with bank credit in firm $i$, sector $j$ and country $c$; $\alpha_{j}$ and $\alpha_{c}$ are sector and country fixed effects; $X_{i j c}$ is a vector of firm-specific variables; Small $_{i j c}$ is a dummy variable equivalent to 1 if the firm is small; $\operatorname{Inf} f_{c}$ is a measure of information sharing in country $c$; $C R_{c}$ is a measure of creditors' legal protection, and $\varepsilon_{i j c}$ is a normal error term. In some specifications, we include interaction terms between $\operatorname{Inf} f_{c}$ and $C R_{c}$.

We expect a negative coefficient for the Small and Medium dummies, since small and mediumsized firms have less access to bank credit than large firms (our control group). Our main variables of interest are size dummies interacting with $C R$ and Inf. We expect a positive sign for each of these four variables. Improvements in creditor rights or the introduction of credit registries (better information) should increase access to bank credit for all firms (main effect) but in particular for SMEs (additional effect).

We control for country-level fixed effects to capture any institutional or macroeconomic variable that may also affect access to bank credit. In particular, the country dummies account for the main effect of stronger legal rights for creditors and information sharing. Given that the size dummies interact with variables that do not vary at the country level, we use clustered standard errors to adjust them. ${ }^{8}$ This is extremely important, since the variables that interact with the size variables do not vary at the firm level but only at the country level. Moulton (1990) demonstrated the serious downward biases in the estimated standard errors that can result from estimating the effects of aggregate explanatory variables on individual-specific (firm-specific, in this case) response variables. Clustered standard errors help to reduce that bias. We weight observations by the inverse of the number of firms in each country-size cell to control for the different number of firms across countries. ${ }^{9}$ We also control for sector-specific effects.

7 The Hausman-McFadden specification test for IIA rejects the null hypothesis that coefficients for the model with and without country dummies are the same (chi(13)=78.6).

8 In particular, we cluster at the country-size level. See Moulton (1990) and Judson and Owen (1996).

9 Without weights, countries with more observations will drive the results, although our variables of interest vary only across countries. 
The choice of our empirical methodology is closely related to recent research by Greene on fixed effects in limited dependent variable models. The authors of many firm-level studies have opted to use random-effect Tobit models to estimate the impact of country-wide variables on firm-specific truncated indicators, such as the share of investment financed by credit, in which accounting for individual effects appears relevant. ${ }^{10}$ However, Greene (2002 and 2004) shows that, if the explanatory variables are not uncorrelated with the individual effects (a usually unpalatable assumption), the random-effect model can lead to biased estimates of the model's slope parameters. In such a case, the fixed-effect Tobit is a preferable methodology, given that the bias in the slope parameters attributed to the incidental parameter problem tends to be negligible.

Country-level fixed effects allow us to deal with observed and unobserved country-specific components, as well as, in some cases, partial endogeneity and inverse causality. Any increase in total credit that induces the development of credit bureaux and creditor protection mechanisms is controlled for by the fixed effect. Only pathological changes in the relative amount of credit to SMEs that imply changes in credit registries and creditor rights at the country level will not be taken into account by the country fixed effect; thus, some scope for reverse causality will remain.

\section{Data}

This section describes the data sources and variables used in the empirical analysis. Our main source of data is the World Business Environment Survey (WBES); ${ }^{11}$ other sources include several research papers that provide valuable information on the development of credit bureaux and creditor protection regulations around the world. ${ }^{12}$ For the purposes of this study, the dependent variable is the leverage of firms of different sizes. Our purpose is to test if access to credit, defined as the share of investment financed with bank credit, depends on the extent of creditors' legal protection, the development of information-sharing mechanisms, the size of firms and/or the interaction between size, on the one hand, and creditor protection and information sharing, on the other.

WBES results provide a firm-level dataset that consists of responses from more than 10,000 firms across the world to questions related to a country's business environment. The survey includes questions regarding firms' financing structure. Business managers were asked to report how much of their investment was financed over the last year from the following sources: (i) retained earnings, (ii) funds from family and friends, (iii) equity, (iv) supplier credit, (v) leasing arrangements, (vi) money lenders, (vii) other public-sector support, (viii) local commercial banks, (ix) foreign banks, (x) development banks, and (xi) other. For our purposes, we define the dependent variable as the sum of the portion of investment financed with credit provided by local commercial banks and foreign banks and label this as "access to bank credit."

When constructing the "access to bank credit" variable, we took great care to exclude erroneous data. We dropped all firms that reported percentages for funding sources that totalled less than $90 \%$ or more than $110 \%$. Thus, we allowed for the possibility of small mistakes in addition, but eliminated excessively erroneous data.

Another crucial firm-level variable in our analysis is the size of firms. These data were also obtained from WBES, which classifies firms into three different groups by size: small firms are defined as those with more than 5 but fewer than 50 workers; medium-sized firms are those with more than 50

\footnotetext{
10 See, for example, Beck, Demirgüç-Kunt and Maksimovic (2001).

11 This dataset has been used in various cross-country studies. See, for example, Beck, Demirgüç-Kunt and Maksimovic (2005) and Beck and others (2006).

12 See, for example, La Porta and others (1997 and 1998) and Djankov, McLiesh and Shleifer (2007).
} 
but fewer than 500 employees; and large firms are those with more than 500 workers. Other firmlevel variables included in our empirical analysis that can affect access to finance are the ownership structure of the firm (foreign- or State-owned), export orientation and the economic sector in which the firm operates. ${ }^{13}$

Table 1 reports some basic descriptive statistics for the dependent variable in our study for the 61 countries in which creditor protection laws and credit bureau data can be matched up with WBES data. The average firm in our sample finances $16.2 \%$ of its investment with bank credit. As expected, large firms finance a bigger share of investment with credit than medium-sized and small ones do, since large firms face lower information asymmetries and have more collateral, and they therefore find it easier to gain access to credit markets. Export firms, defined as firms for which exports represent at least $1 \%$ of their total sales, have greater access to credit than other firms. This may be due to the fact that export activity signals high productivity and thus high repayment probabilities to creditors and hence eases financial constraints. This would hold true for firms of all sizes. In the sample there are no relevant unconditional differences between the shares of investment financed by small and mediumsized foreign-owned firms.

Table 1

Share of investment financed with bank credit: descriptive statistics (In levels and percentages)

\begin{tabular}{lllccc}
\hline & & All & Export binary & Foreign binary & State-owned firms \\
\hline \multirow{2}{*}{$\begin{array}{lllll}\text { All } \\
\text { 6 616 }\end{array}$} & Mean & 16.2 & 23.2 & 11.6 & 23.3 \\
\cline { 2 - 6 } $\begin{array}{l}\text { Small } \\
2803\end{array}$ & Standard deviation & 27.0 & 30.4 & 24.1 & 31.7 \\
\hline \multirow{2}{*}{$\begin{array}{l}\text { Medium } \\
2797\end{array}$} & Mean & 11.3 & 17.5 & 12.1 & 14.2 \\
\hline \multirow{nyyyy}{*}{$\begin{array}{l}\text { Large } \\
1014\end{array}$} & Standard deviation & 22.8 & 26.8 & 27.4 & 26.1 \\
\hline
\end{tabular}

Source: Prepared by the authors, on the basis of World Bank, World Business Environment Survey (WBES).

a Not all firms record this variable, so the total does not correspond to the sum of firms by size.

To measure the development of credit registries, we use data from the Doing Business project of the World Bank. Our main variables are the presence of any credit registry, a dummy variable equivalent to 1 if there is a public credit registry or a private credit bureau, and the coverage of private and public registries. Private credit bureau coverage reports the number of individuals or firms listed by a private or public credit bureau with information on repayment history, unpaid debts or credit outstanding. The number is expressed as a percentage of the adult population. We construct an index taking the larger of the two as the relevant variable for the economy, and we also explore the role of each type of coverage individually. For example, if a country has a private credit bureau that covers 550 per 1,000 of the population and a public credit registry that covers 200 per 1,000 of the population only, we use the larger of the two (550). The reason for doing this is to avoid double counting borrowers (many of whom may appear in both registries). In a non-reported exercise, we use each of the coverage measures separately. This measure gives us some insights into how many SMEs may be covered by credit registries. For example, for the case of Chile, a mid-developed country in our sample, the private credit registry has 227 entries per 1,000 adults. For that same year, Chile had

\footnotetext{
${ }^{13}$ The dataset does not include the number of employees, sales figures or the level of assets. This study therefore uses the only size variable available.
} 
1.9 large firms per 1,000 adults, 1.5 medium-sized firms per 1,000 adults, and 25 small firms and 123 micro-enterprises per 1,000 adults. ${ }^{14}$ The annex reports the countrywide data used in the study.

To proxy the status of creditors' legal protection, we use a set of variables that has frequently been cited in related literature. ${ }^{15}$ These variables are measures of certain types of institutions and of rules and regulations that directly affect creditors' ability to seize collateral effectively and efficiently. ${ }^{16}$ Following Galindo and Micco (2007), we use a measurement of effective creditor rights that combines a legal variable that reflects creditor protection based on La Porta and others (1997) and an indicator of the rule of law (derived from the World Bank). This variable captures not only the regulatory framework surrounding the rights of creditors in bankruptcy proceedings but also the extent of enforcement of bankruptcy laws. We also proxy the protection of creditor rights using the type of legal system that is in place. ${ }^{17}$ We draw here on the proposition espoused by La Porta and others (1997) that countries with common law systems are characterized by better creditor protection.

Figure 1 and table 2 report some basic statistics that underlie the econometric study. Figure 1 shows the average share of investment that has been financed with bank credit for firms of different sizes in countries in which the development of credit bureaux has reached differing levels (see figure $1 \mathrm{~A})^{18}$ and which have differing legal systems (see figure 1B).

The development of credit bureaux is measured as the portion of the population that is covered either by a private credit bureau or a public credit registry. We split the sample between countries with coverage higher or lower than $1 \%$, with the aim of having a similar number of countries in each group. As expected, larger firms are able to access more credit to finance their investment. However, in countries with stronger credit registries, firms of all sizes have more available credit than they do in countries in which the presence of credit bureaux is weaker. The difference in access to credit is proportionally greater for small firms. We find similar results when we split the sample between common-law and non-common-law countries. In both groups, large firms have more access to credit than small firms do, but this difference is fairly small in common-law countries.

In addition, in table 2, the sample is divided between countries with high and low coverage indices for credit registries or credit bureaux, using as a threshold a coverage level of $1 \%$ of the total population (10\%); the sample is also divided according to the level of protection of creditors' rights. As expected, in each quadrant, the share of investment financed with bank credit increases with the size of the firms involved. Also as expected, the share of finance is larger in countries with stronger creditor protection for any given segment of firm size. What is particularly interesting to note is how the share of credit in small firms reaches a similar level in countries with strong creditor protection and no credit registry and in countries with weak creditor protection and a credit registry. The presence of a credit bureau or a credit registry therefore seems to compensate for deficiencies in creditor rights regulations. This finding is important for developing countries, since it appears that a weak institutional set-up in the financial sector, which could be hard to rectify in the short term, may be compensated for by a greater supply of information.

\footnotetext{
14 In Chile, large, medium-sized and small firms are defined as those having annual sales above US\$ 3.8 million, US\$ 961,000, and US\$92,000, respectively.

15 See La Porta and others (1997 and 1998) and Galindo and Micco (2007).

${ }^{16}$ The creditor rights index measures: (i) whether there are restrictions, such as creditor consent, when a debtor files for reorganization; (ii) whether secured creditors are able to seize their collateral after the petition for reorganization is approved (in other words, whether there is no "automatic stay" or court-ordered "asset freeze"); (iii) whether secured creditors are paid first out of the proceeds of the liquidation of a bankrupt firm, and (iv) whether an administrator, as opposed to management, is responsible for running the business during the reorganization.

17 Several authors have linked a common-law legal tradition with better protection for creditors. See, for example, La Porta and others (1997 and 1998).

18 We use a maximum coverage of $1 \%(10 / 100)$ as a cutoff.
} 
Figure 1

Share of investment financed with bank credit, by firm size

(In percentages)

A. Countries with highly and less highly developed credit reporting institutions

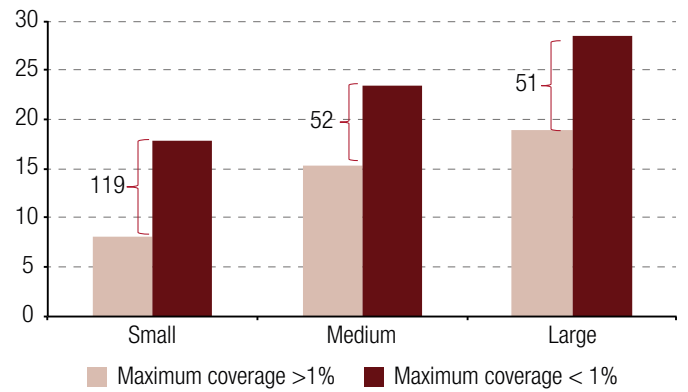

B. Common-law and non-commonlaw countries

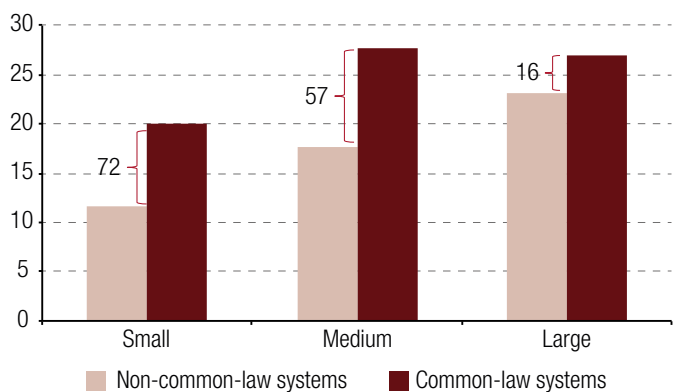

Source: Prepared by the authors, on the basis of World Bank, World Business Environment Survey (WBES).

Note: These figures do not include Portugal because it has the same number of observations in each group.

Table 2

Average share of investment financed with bank credit, by firm size, presence or absence of information-sharing mechanisms and type of legal system

(In percentages)

\begin{tabular}{|c|c|c|c|c|c|c|}
\hline & \multicolumn{3}{|c|}{ Non-common-law countries } & \multicolumn{3}{|c|}{ Common-law countries } \\
\hline & Small & Medium & Large & Small & Medium & Large \\
\hline No private or public registry & 5.4 & 10.3 & 13.6 & 25.9 & 34.4 & 35.0 \\
\hline Number of countries & 18 & 18 & 18 & 4 & 4 & 4 \\
\hline Private or public registry & 15.2 & 21.7 & 28.7 & 16.8 & 24.0 & 22.3 \\
\hline Number of countries & 32 & 32 & 31 & 7 & 7 & 7 \\
\hline
\end{tabular}

Source: Prepared by the authors, on the basis of World Bank, World Business Environment Survey (WBES).

\section{Baseline results}

Our baseline results are reported in table 3. With respect to firm-level controls, we find that exporters finance around $10 \%$ more of their investment with bank loans than firms that cater to the domestic market. ${ }^{19}$ We do not find significant differences between the shares of financing for State-owned and foreign-owned firms. Finally, although not reported in the tables, firms in the manufacturing sector, perhaps due to the tangibility of their assets, have greater access to bank loans. In a country with an average coverage of credit information (113), small firms finance about 30 percentage points less of their investment with credit than large firms do, while the corresponding differential for medium-sized companies is about 11.5 percentage points. ${ }^{20}$

Focusing on the variables of interest for this study, we find that the development of creditsharing mechanisms alters the financing gap between large and small firms. Column 1 indicates that a one-standard-deviation increase in the coverage of credit information-sharing institutions (119 per 1,000 inhabitants) above the average (113) reduces the financing gap between large and small

\footnotetext{
${ }^{19}$ As a measure of robustness, we use a different definition of export firms (exports $>10 \%$ of sales) but the results do not change.

20 These results come from column 1. To compute the value for small and medium-sized firms, we take CL=0.5 ( $C L$ is either 0 or 1) and max coverage $=113$ (the average maximum coverage in the sample): $-30=-48+0.07 \times 113+19.9 \times 0.5$.
} 
firms to nearly 22 percentage points (from 30 points) and the gap between large and medium-sized firms to 8.5 percentage points (from 11.5). ${ }^{21}$ The effect of information-sharing mechanisms is not only statistically significant, but also is actually quite large in relation to the prevailing financing gaps between large and small firms.

Column 2 also shows that the presence of credit-sharing institutions is influential in explaining the financing gap between large and small firms. Our dummy variable for the presence of a public registry or a private credit bureau indicates that the presence of a credit registry reduces the gap between large and small firms by 39 percentage points. For medium-sized firms, the gap narrows by 17 percentage points. Column 3 shows qualitatively similar results when dummy variables are used for the presence of information-sharing institutions and their coverage. The presence of credit information institutions significantly increases firms' access to credit, with a differential impact being observed for smaller ones.

Table 3

Baseline econometric results

\begin{tabular}{|c|c|c|c|c|c|c|c|c|}
\hline $\begin{array}{l}\text { Dependent variable: share of investment } \\
\text { financed by bank credit (firm level) }\end{array}$ & (1) & (2) & (3) & (4) & (5) & (6) & (7) & (8) \\
\hline \multirow{2}{*}{ Export firms } & 10.546 & 10.195 & 10.191 & 10.174 & 9.690 & 10.248 & 9.812 & 3.781 \\
\hline & {$[2.369]^{\star \star \star}$} & {$[2.366]^{\star \star *}$} & {$[2.379]^{\star \star \star}$} & {$[2.359]^{\star \star \star}$} & {$[2.320]^{\star \star \star}$} & {$[2.335]^{\star \star \star}$} & {$[2.339]^{\star \star *}$} & {$[1.058]^{\star \star \star}$} \\
\hline \multirow{2}{*}{ Public ownership (firm) } & -6.535 & -7.740 & -8.106 & -7.613 & -6.550 & -5.634 & -6.903 & -4.265 \\
\hline & {$[4.201]$} & {$[4.216]^{\star}$} & {$[4.224]^{*}$} & {$[4.224]^{\star}$} & {$[4.177]$} & [4.182] & [4.212] & {$[1.741]^{\star \star}$} \\
\hline \multirow{2}{*}{ Foreign ownership (firm) } & -0.266 & -0.250 & -0.039 & -0.336 & -0.266 & -0.462 & -0.232 & 0.116 \\
\hline & [3.080] & [3.075] & {$[3.071]$} & [3.076] & [3.067] & [3.093] & [3.064] & {$[1.456]$} \\
\hline \multirow{2}{*}{ Small firms } & -48.184 & -66.341 & -64.858 & -68.018 & -57.882 & -43.239 & -58.035 & -10.690 \\
\hline & {$[4.980]^{\star \star \star}$} & {$[9.290]^{\star \star \star}$} & {$[9.295]^{\star \star \star}$} & {$[9.323]^{\star \star \star}$} & {$[8.264]^{\star \star \star}$} & {$[4.794]^{\star \star \star}$} & {$[8.339]^{\star \star \star}$} & {$[1.702]^{\star \star \star}$} \\
\hline \multirow{2}{*}{ Medium-sized firms } & -23.681 & -32.804 & -32.696 & -34.610 & -27.403 & -19.078 & -27.365 & -3.627 \\
\hline & {$[4.007]^{\star \star \star}$} & {$[6.859]^{\star \star \star}$} & {$[6.879]^{\star \star \star}$} & {$[7.199]^{\star \star \star}$} & {$[6.080]^{\star \star *}$} & {$[3.735]^{\star \star \star}$} & {$[6.121]^{\star \star \star}$} & {$[1.346]^{\star \star \star}$} \\
\hline Credit registry coverage & 0.070 & & 0.042 & & & 0.058 & 0.028 & 0.013 \\
\hline Small firms & {$[0.013]^{\star \star *}$} & & {$[0.017]^{\star \star}$} & & & {$[0.013]^{\star \star \star}$} & {$[0.016]^{*}$} & {$[0.005]^{\star \star}$} \\
\hline Credit registry coverage & 0.025 & & 0.010 & & & 0.015 & -0.001 & 0.004 \\
\hline Medium-sized firms & {$[0.010]^{\star \star}$} & & {$[0.011]$} & & & {$[0.011]$} & {$[0.014]$} & {$[0.004]$} \\
\hline Private or public registry & & 39.089 & 28.189 & 35.888 & 33.617 & & 27.299 & \\
\hline Small firms & & {$[8.962]^{\star \star \star}$} & {$[10.500]^{\star \star \star}$} & {$[11.144]^{\star \star \star}$} & {$[8.315]^{\star \star \star}$} & & {$[9.401]^{\star \star \star}$} & \\
\hline Private or public registry & & 17.511 & 15.440 & 13.970 & 14.934 & & 15.243 & \\
\hline Medium-sized firms & & {$[6.817]^{\star *}$} & {$[7.682]^{\star \star}$} & {$[7.934]^{\star}$} & {$[6.464]^{\star \star}$} & & {$[7.423]^{\star \star}$} & \\
\hline Registry with positive information & & & & 5.787 & & & & \\
\hline Small firms & & & & {$[9.737]$} & & & & \\
\hline Registry with positive information & & & & 6.296 & & & & \\
\hline Medium-sized firms & & & & 6.296 & & & & \\
\hline Common-law country & 19.878 & 32.019 & 26.009 & 32.643 & & & & 6.510 \\
\hline Small firms & {$[7.833]^{\star \star}$} & {$[9.042]^{\star \star *}$} & {$[9.966]^{\star \star \star}$} & {$[8.783]^{\star \star \star}$} & & & & {$[2.623]^{\star \star}$} \\
\hline Common-law country & 18.764 & 22.334 & 21.293 & 23.023 & & & & 7.884 \\
\hline Medium-sized firms & {$[5.407]^{\star \star \star}$} & {$[5.588]^{\star \star \star}$} & {$[5.838]^{\star \star \star}$} & {$[5.675]^{\star \star \star}$} & & & & {$[2.369]^{\star \star \star}$} \\
\hline Effect of creditor rights (country) & & & & & 26.992 & 17.790 & 21.639 & \\
\hline Small firms & & & & & {$[4.522]^{\star \star \star}$} & {$[5.052]^{\star \star \star}$} & {$[5.551]^{\star \star \star}$} & \\
\hline
\end{tabular}

${ }^{21}$ For small firms, the estimated reduction in the credit gap is $119^{*} 0.07$, while for medium-sized firms it is $119^{\star} 0.025$. 
Table 3 (concluded)

\begin{tabular}{|c|c|c|c|c|c|c|c|c|}
\hline $\begin{array}{l}\text { Dependent variable: share of investment } \\
\text { financed by bank credit (firm level) }\end{array}$ & (1) & (2) & (3) & (4) & (5) & (6) & (7) & (8) \\
\hline Effect of creditor rights (country) & & & & & 17.416 & 15.430 & 17.627 & \\
\hline Medium-sized firms & & & & & {$[4.425]^{\star \star \star}$} & {$[4.729]^{\star \star \star}$} & {$[5.099]^{\star \star \star}$} & \\
\hline Observations & 6470 & 6604 & 6604 & 6604 & 6470 & 6604 & 6604 & 6604 \\
\hline Country fixed effects & Yes & Yes & Yes & Yes & Yes & Yes & Yes & Yes \\
\hline Sector fixed effects & Yes & Yes & Yes & Yes & Yes & Yes & Yes & Yes \\
\hline Number of countries & 61 & 61 & 61 & 61 & 61 & 61 & 61 & 61 \\
\hline
\end{tabular}

Source: World Bank, World Business Environment Survey (WBES) and S. Djankov, C. McLiesh and A. Shleifer, "Private credit in 129 countries", Journal of Financial Economics, vol. 84, No. 2, Amsterdam, Elsevier, 2007.

Note: Robust standard errors in brackets. Clusters by country size. * significant at $10 \%$; ${ }^{* *}$ significant at $5 \%$; ${ }^{* * *}$ significant at $1 \%$.

Column 4 shows if there is a difference between credit registries which include positive information (a good record of repayment) and credit registries that include only negative information in their credit reports. We do not find any statistically significant difference between the inclusion of positive and negative versus solely negative information in credit reports.

A non-reported regression includes additional interactions that separate the coverage of public credit registries and private credit bureaux. The results suggest that the impact on small and mediumsized firms is not significantly different when discriminating between the two types of institutions, although the impact on medium-sized firms appears to be driven mostly by information coming from private credit bureaux.

To study the role of legal protection for creditors, we include the interaction of the firm-size dummies with measures of credit rights protection. In columns 1 to 4 , we interact firm size with a dummy that indicates if a country has a common-law regime, which has been proven to be a good proxy for effective creditor rights (CL). The credit gap between small and large firms is between 20 and 30 percentage points smaller in countries with common-law regimes than in countries with other legal systems. For medium-sized enterprises, the gap with large firms narrows by between 18 and 32 percentage points.

Following Galindo and Micco (2007), in columns 5 to 7, we interact size with an indicator of effective creditors' rights protection based on the interaction outlined by La Porta and others (1997 and 1998) between creditor rights and the rule of law indicator from the Worldwide Governance Indicators dataset. ${ }^{22}$ We find very strong results for the impact of creditor rights regulations in reducing the financing gap between small and large firms and between medium-sized and large firms. A onestandard-deviation increase in our measure of effective creditors' rights $(0.516)$ reduces the gap between small and large firms by from 9 to 14 percentage points and the gap between medium-sized and large firms by between 8 and 9 percentage points. In a non-reported regression in which we use the logarithm of the number of days that the justice system takes to enforce a contract as a measure of creditor protection, we find similar results.

Finally, in column 8 we re-do the specification in column 1 using ordinary least squares (OLS). Estimated coefficients have the same expected sign and are significant at conventional levels. Not surprisingly, due to the censoring nature of the data, estimated slopes are smaller in absolute values.

The main policy driver in the reduction of the financing gap is an improvement in the protection of creditors' rights. Nonetheless, and especially for small firms, the effort to strengthen effective creditor rights - a titanic task - can be bolstered by efforts to develop information-sharing mechanisms. These

22 See Kaufmann, Kraay and Mastruzzi (2009). 
efforts will provide a bigger pay-off if the benefits of information mechanisms are larger in countries with poor creditor protection. To test this hypothesis, columns 1-2 and 4-5 in table 3 are computed in table 4 while including an interaction term between information-sharing and creditor protection. For each of the four specifications, the interaction term is negative for small and medium-sized firms and is statistically significant in all cases for small firms. This implies that the beneficial effect of informationsharing institutions is larger in countries with poor creditor protection. Non-common-law countries can thus offset the absence of effective creditor rights in their credit markets by establishing informationsharing institutions.

Table 4

Econometric results when controlling for the interaction effect between information sharing and creditor protection

\begin{tabular}{|c|c|c|c|c|}
\hline $\begin{array}{l}\text { Dependent variable: share of investment } \\
\text { financed by bank credit (firm level) }\end{array}$ & (1) & (2) & (3) & (4) \\
\hline \multirow{2}{*}{ Export firms } & 10.300 & 10.000 & 10.084 & 9.499 \\
\hline & {$[2.359]^{\star \star \star}$} & {$[2.339]^{\star \star \star}$} & {$[2.330]^{\star \star \star}$} & {$[2.307]^{\star \star \star}$} \\
\hline \multirow{2}{*}{ Public ownership (firm) } & -7.158 & -8.763 & -5.810 & -6.920 \\
\hline & {$[4.203]^{*}$} & {$[4.212]^{\star \star}$} & {$[4.177]$} & {$[4.165]^{*}$} \\
\hline \multirow{2}{*}{ Foreign ownership (firm) } & 0.037 & -0.278 & -0.522 & -0.263 \\
\hline & {$[3.076]$} & {$[3.057]$} & [3.083] & [3.059] \\
\hline \multirow{2}{*}{ Small firms } & -51.739 & -72.842 & -43.978 & -57.367 \\
\hline & {$[5.693]^{\star \star *}$} & {$[11.168]^{\star \star *}$} & {$[4.888]^{\star \star *}$} & {$[8.188]^{\star \star *}$} \\
\hline \multirow{2}{*}{ Medium-sized firms } & -24.723 & -34.245 & -19.475 & -26.579 \\
\hline & {$[4.551]^{\star \star \star}$} & {$[7.805]^{\star \star \star}$} & {$[3.789]^{\star \star \star}$} & {$[5.927]^{\star \star \star}$} \\
\hline Private or public registry & & 47.353 & & 33.772 \\
\hline Small firms & & {$[11.224]^{\star \star \star}$} & & {$[8.357]^{\star \star *}$} \\
\hline Private or public registry & & 19.290 & & 14.535 \\
\hline Medium-sized firms & & {$[8.177]^{\star \star}$} & & {$[6.368]^{\star \star}$} \\
\hline Credit registry coverage & 0.092 & & 0.073 & \\
\hline Small firms & {$[0.018]^{\star \star \star}$} & & {$[0.018]^{\star \star \star}$} & \\
\hline Credit registry coverage & 0.032 & & 0.024 & \\
\hline Medium-sized firms & {$[0.015]^{\star \star}$} & & {$[0.014]^{\star}$} & \\
\hline Common law (country) & 31.556 & 55.616 & & \\
\hline Small firms & {$[11.397]^{\star \star \star}$} & {$[13.229]^{\star \star *}$} & & \\
\hline Common law (country) & 22.476 & 30.022 & & \\
\hline Medium-sized firms & {$[7.154]^{\star \star \star}$} & {$[10.190]^{\star \star \star}$} & & \\
\hline Effective creditor rights (country) & & & 23.826 & 44.053 \\
\hline Small firms & & & {$[6.171]^{\star \star \star}$} & {$[9.157]^{\star \star *}$} \\
\hline Effective creditor rights (country) & & & 17.629 & 30.435 \\
\hline Medium-sized firms & & & {$[5.607]^{\star \star \star}$} & {$[7.786]^{\star \star \star}$} \\
\hline Private or public registry $\mathrm{x}$ common law & & -35.180 & -0.037 & 0.000 \\
\hline Small firms & & {$[17.419]^{\star \star}$} & & \\
\hline Private or public registry $\mathrm{x}$ common law & & -10.944 & & \\
\hline Medium-sized firms & & [12.285] & & \\
\hline Credit registry coverage $\mathrm{x}$ common law & -0.051 & & & \\
\hline Small firms & {$[0.025]^{\star \star}$} & & & \\
\hline Credit registry coverage $\mathrm{x}$ common law & -0.017 & & & \\
\hline Medium-sized firms & [0.019] & & & \\
\hline Private or public registry $\mathrm{x}$ effective creditor rights & & & & -26.367 \\
\hline Small firms & & & & {$[10.542]^{\star \star}$} \\
\hline
\end{tabular}


Table 4 (concluded)

\begin{tabular}{|c|c|c|c|c|}
\hline $\begin{array}{l}\text { Dependent variable: share of investment } \\
\text { financed by bank credit (firm level) }\end{array}$ & (1) & (2) & (3) & (4) \\
\hline Private or public registry $\mathrm{x}$ effective creditor rights & & & & -20.811 \\
\hline Medium-sized firms & & & & {$[9.425]^{\star \star}$} \\
\hline Credit registry coverage $x$ effective creditor rights & & & -0.037 & \\
\hline Small firms & & & {$[0.018]^{\star *}$} & \\
\hline Credit registry coverage $x$ effective creditor rights & & & -0.020 & \\
\hline Medium-sized firms & & & {$[0.015]$} & \\
\hline Observations & 6604 & 6604 & 6604 & 6604 \\
\hline Country fixed effects & Yes & Yes & Yes & Yes \\
\hline Sector fixed effects & Yes & Yes & Yes & Yes \\
\hline Number of countries & 61 & 61 & 61 & 61 \\
\hline
\end{tabular}

Source: World Bank, World Business Environment Survey (WBES) and S. Djankov, C. McLiesh and A. Shleifer, "Private credit in 129 countries", Journal of Financial Economics, vol. 84, No. 2, Amsterdam, Elsevier, 2007.

Note: Robust standard errors are shown in brackets. Clusters are by country size. * significant at $10 \%$; ** significant at $5 \%$; ${ }^{* * *}$ significant at $1 \%$.

In summary, our baseline results suggest that creditors' legal protection and the development of either private or public credit reporting institutions are strongly correlated with access to credit markets, particularly for small firms. In the next section, we control for the level of development and different subsamples in order to gain a greater understanding of the robustness of these findings.

\section{Robustness}

A possible driver of our previous results is that the measurements used to capture the development of credit information institutions or legal protection for creditors are proxies for economic development. Most probably, more developed countries have more robust credit-reporting institutions and stronger effective creditor rights (by virtue of a steadfast respect for the rule of law). In order to deal with this possible bias, we control for economic development in two possible ways: first, by using dummy variables that indicate if a country is a low- or middle-income country according to the World Bank classification (columns 1 to 4 in table 5) and, second, by using purchasing power parity (PPP) GDP per capita (columns 5 and 6). As above, we include both measures of credit information development -the maximum coverage variable and the dummy variable - as well as our measure of creditors' legal protection. The results remain qualitatively the same. While there is a reduction in the point estimates of the maximum coverage variable and the credit registry dummy, the results still point in the same direction: credit registries play a significant role in reducing the financing gap between small and large firms. Not surprisingly, effective creditor rights - our proxies for creditor legal protection, which include the rule of law - are weaker when we include controls for levels of income but, in most specifications, they remain significant. In the case of common-law countries, the results are the same as before.

Table 5

Econometric results when controlling for income level

\begin{tabular}{|c|c|c|c|c|c|c|c|}
\hline $\begin{array}{l}\text { Dependent variable: share } \\
\text { of investment financed by } \\
\text { bank credit (firm level) }\end{array}$ & (1) & (2) & (3) & (4) & (5) & (6) & (7) \\
\hline \multirow{2}{*}{ Export firms } & 9.627 & 9.959 & 9.536 & 9.956 & 9.707 & 9.635 & 10.139 \\
\hline & {$[2.344]^{\star \star \star}$} & {$[2.349]^{\star \star \star}$} & {$[2.340]^{\star \star \star}$} & {$[2.355]^{\star \star *}$} & {$[2.337]^{\star \star *}$} & {$[2.324]^{\star \star \star}$} & {$[2.344]^{\star \star \star}$} \\
\hline \multirow{2}{*}{ Public ownership (firm) } & -7.036 & -5.403 & -6.210 & -5.067 & -6.517 & -5.964 & -5.150 \\
\hline & {$[4.238]^{*}$} & {$[4.209]$} & [4.234] & [4.208] & [4.239] & [4.230] & [4.220] \\
\hline
\end{tabular}


Table 5 (concluded)

\begin{tabular}{|c|c|c|c|c|c|c|c|}
\hline $\begin{array}{l}\text { Dependent variable: share } \\
\text { of investment financed by } \\
\text { bank credit (firm level) }\end{array}$ & (1) & (2) & (3) & (4) & (5) & (6) & (7) \\
\hline \multirow{2}{*}{ Foreign ownership (firm) } & 0.256 & 0.004 & -0.026 & -0.280 & -0.223 & -0.283 & -0.434 \\
\hline & [3.108] & [3.108] & [3.097] & [3.117] & [3.086] & [3.088] & [3.092] \\
\hline \multirow{2}{*}{ Small firms } & -35.353 & -22.886 & -34.358 & -23.535 & -62.474 & -56.641 & -45.276 \\
\hline & {$[11.982]^{\star \star \star}$} & {$[10.704]^{\star \star}$} & {$[13.548]^{\star \star}$} & {$[13.637]^{*}$} & {$[9.231]^{\star \star \star}$} & {$[8.552]^{\star \star \star}$} & {$[4.992]^{\star \star \star}$} \\
\hline \multirow{2}{*}{ Medium-sized firms } & -24.777 & -17.529 & -31.952 & -24.138 & -31.139 & -27.550 & -21.946 \\
\hline & {$[9.415]^{\star \star \star}$} & {$[10.071]^{\star}$} & {$[11.696]^{\star \star \star}$} & {$[12.675]^{\star}$} & {$[6.692]^{\star \star \star}$} & {$[6.195]^{\star \star \star}$} & {$[4.010]^{\star \star \star}$} \\
\hline Private or public registry & 29.737 & & 28.967 & & 31.678 & 31.142 & \\
\hline Small firms & {$[8.904]^{\star \star \star}$} & & {$[8.706]^{\star \star \star}$} & & {$[9.075]^{\star \star \star}$} & {$[8.830]^{\star \star \star}$} & \\
\hline Private or public registry & 14.864 & & 15.564 & & 14.716 & 15.452 & \\
\hline Medium-sized firms & {$[6.755]^{\star *}$} & & {$[6.791]^{\star \star}$} & & {$[6.768]^{\star \star}$} & {$[6.750]^{\star *}$} & \\
\hline Credit registry coverage & & 0.036 & & 0.043 & & & 0.044 \\
\hline Small firms & & {$[0.014]^{\star \star}$} & & {$[0.015]^{\star \star \star}$} & & & {$[0.015]^{\star \star \star}$} \\
\hline Credit registry coverage & & 0.015 & & 0.019 & & & 0.010 \\
\hline Medium-sized firms & & {$[0.013]$} & & [0.013] & & & [0.013] \\
\hline Common law (country) & 29.137 & 22.942 & & & 28.716 & & 20.642 \\
\hline Small firms & {$[8.062]^{\star \star \star}$} & {$[7.375]^{\star \star \star}$} & & & {$[8.582]^{\star \star \star}$} & & {$[7.238]^{\star \star \star}$} \\
\hline Common law (country) & 23.359 & 21.660 & & & 21.671 & & 19.827 \\
\hline Medium-sized firms & {$[5.958]^{\star \star \star}$} & {$[6.252]^{\star \star *}$} & & & {$[5.616]^{\star \star \star}$} & & {$[5.557]^{\star \star \star}$} \\
\hline Effective creditor rights (country) & & & 13.902 & 8.297 & & 19.634 & \\
\hline Small firms & & & {$[7.172]^{\star}$} & [7.116] & & {$[8.328]^{\star \star}$} & \\
\hline Effective creditor rights (country) & & & 19.508 & 16.569 & & 19.088 & \\
\hline Medium-sized firms & & & {$[6.943]^{\star \star \star}$} & {$[6.734]^{\star \star}$} & & {$[7.222]^{\star \star \star}$} & \\
\hline Low-income (country) & -47.813 & -44.401 & -34.878 & -34.416 & & & \\
\hline Small firms & {$[11.840]^{\star \star \star}$} & {$[13.013]^{\star \star \star}$} & {$[16.606]^{\star *}$} & {$[17.690]^{*}$} & & & \\
\hline Low-income (country) & -14.649 & -14.271 & 6.737 & 5.266 & & & \\
\hline Medium-sized firms & {$[8.295]^{*}$} & [10.927] & [13.954] & [15.965] & & & \\
\hline Middle-income (country) & -23.197 & -17.893 & -20.339 & -15.815 & & & \\
\hline Small firms & {$[7.859]^{\star \star \star}$} & {$[9.106]^{\star *}$} & {$[10.496]^{*}$} & [12.288] & & & \\
\hline Middle-income (country) & -4.600 & -2.620 & 4.544 & 5.679 & & & \\
\hline Medium-sized firms & [7.110] & [8.569] & [9.690] & [11.266] & & & \\
\hline Ln per capita GDP (country) & & & & & 12.670 & 6.009 & 10.659 \\
\hline Small firms & & & & & {$[3.841]^{\star \star \star}$} & [5.984] & {$[4.113]^{\star \star \star}$} \\
\hline Ln per capita GDP (country) & & & & & 5.381 & -1.660 & 5.826 \\
\hline Medium-sized firms & & & & & {$[2.872]^{*}$} & [4.909] & {$[3.700]$} \\
\hline Observations & 6604 & 6604 & 6604 & 6604 & 6604 & 6604 & 6604 \\
\hline Country fixed effects & Yes & Yes & Yes & Yes & Yes & Yes & Yes \\
\hline Sector fixed effects & Yes & Yes & Yes & Yes & Yes & Yes & Yes \\
\hline Number of countries & 61 & 61 & 61 & 61 & 61 & 61 & 61 \\
\hline
\end{tabular}

Source: World Bank, World Business Environment Survey (WBES) and S. Djankov, C. McLiesh and A. Shleifer, "Private credit in 129 countries", Journal of Financial Economics, vol. 84, No. 2, Amsterdam, Elsevier, 2007.

Note: Robust standard errors are shown in brackets. Clusters are by country size. * significant at $10 \%$; ** significant at $5 \%$; ${ }^{\star * \star}$ significant at $1 \%$. Ln $=$ Logarithmus naturalis.

Table 6 reports estimates for information sharing and creditors' legal protection using the specification from column 2 in table 3 but while dropping one country from our sample at a time. In all cases, our main estimated coefficients are positive and significant at conventional confidence intervals. 


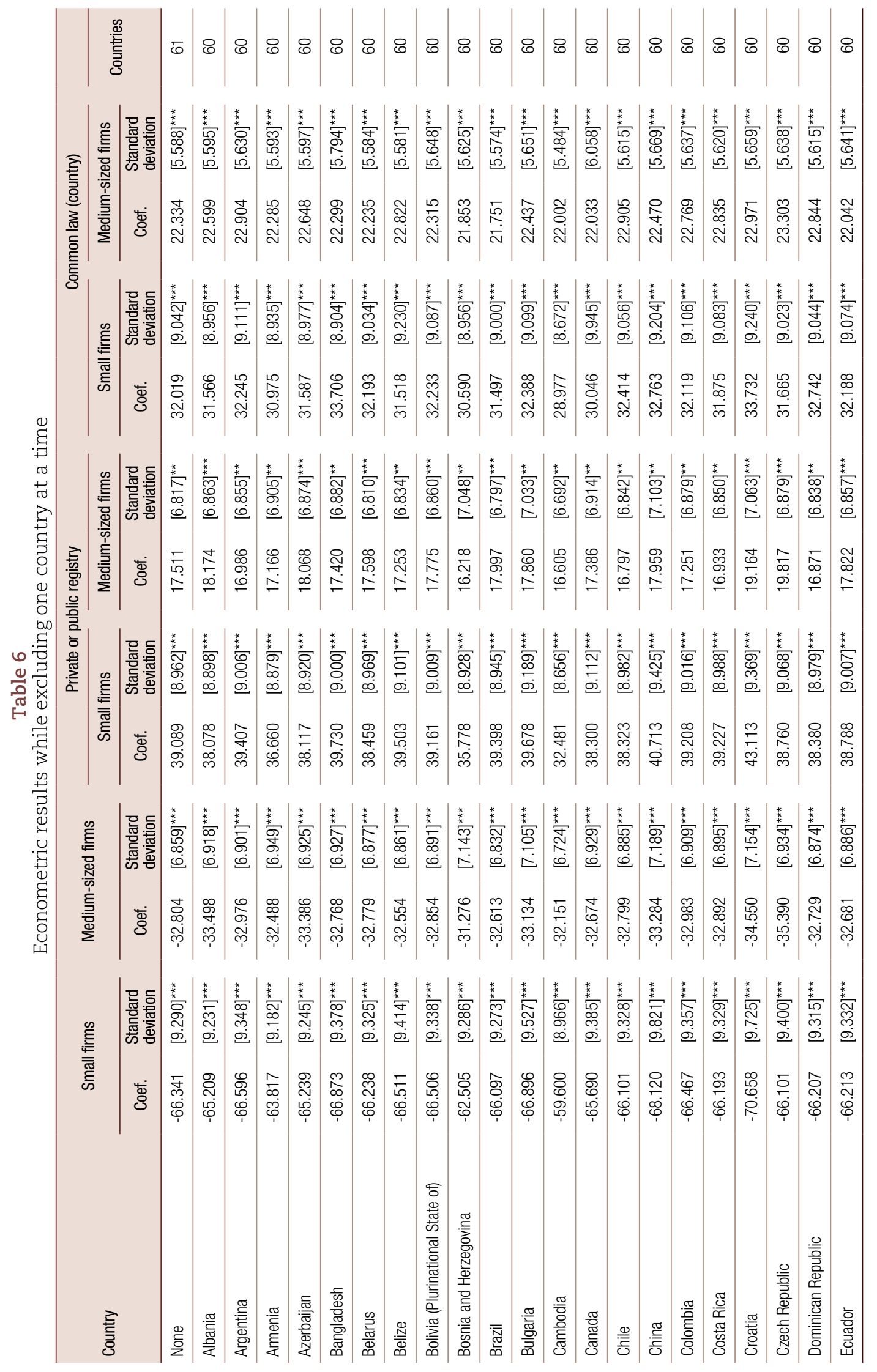




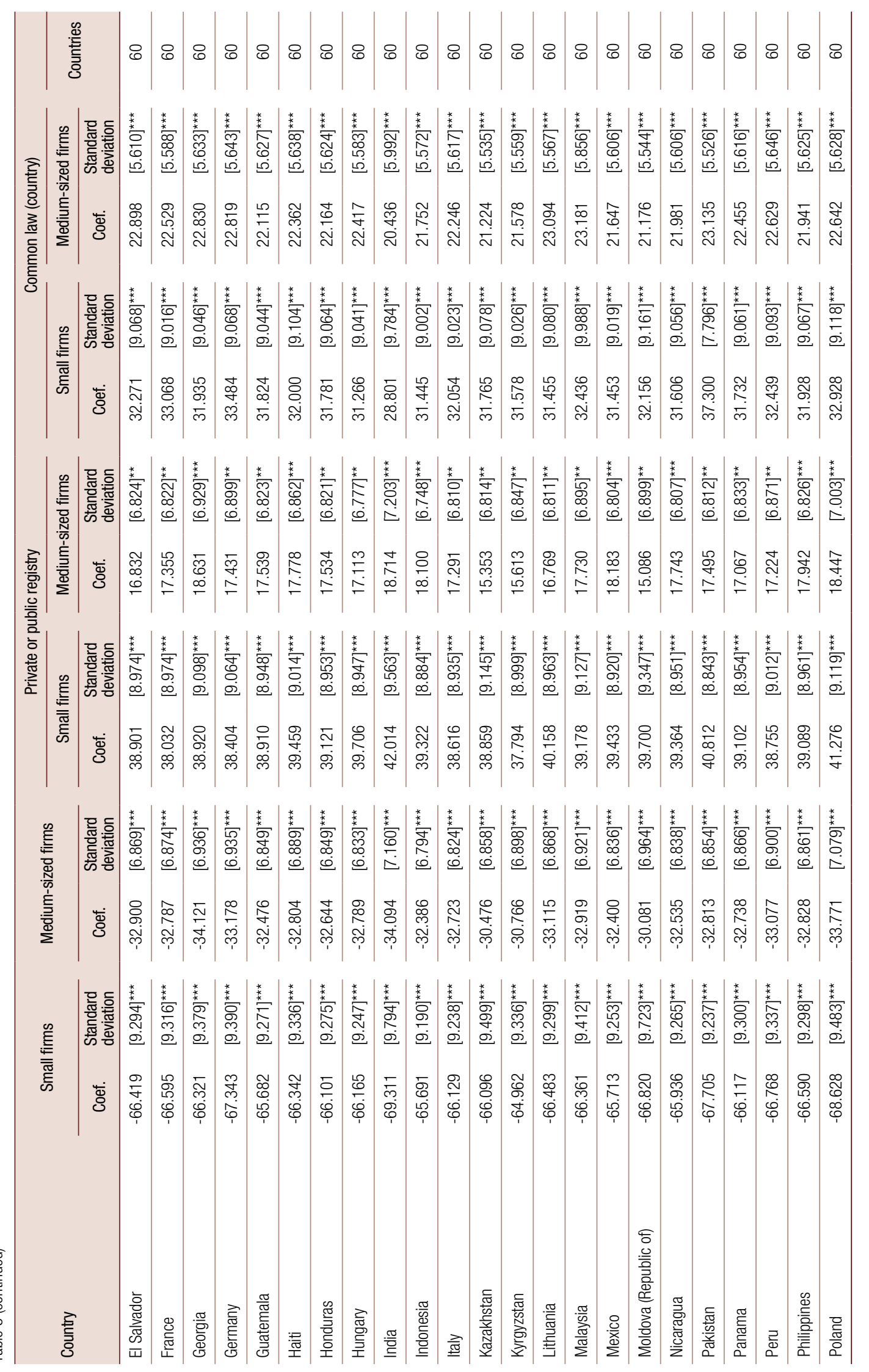




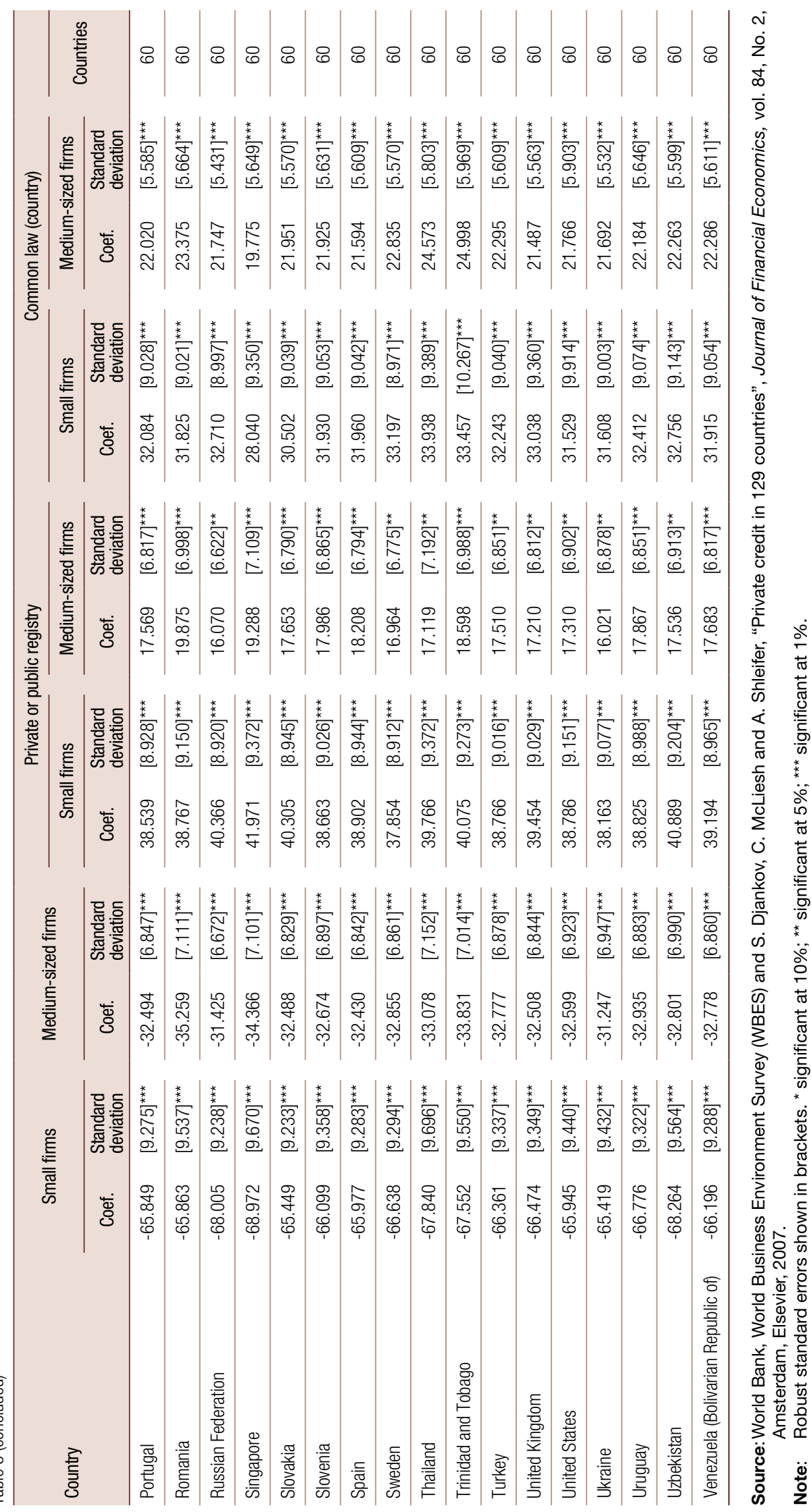




\section{Final remarks}

Using a sample of 61 countries, this study provides empirical evidence that points to the importance of creditor protection and the development of information-sharing mechanisms in opening up access to bank credit for firms of different sizes. We use limited dependent variable techniques to test if the development of information-sharing institutions, such as private credit bureaux or public credit registries, helps to reduce the financing gap between large companies and small and medium-sized enterprises. Using country dummies, we control for any country-omitted variable, which has been one of the major problems in previous studies on this topic.

Our results suggest that improving the coverage of private credit bureaus and public credit registries has a statistically significant effect in terms of a reduction in the gap between the percentage of investment financed with bank credit for large firms and small firms. The results obtained in this study are not only statistically significant, but are also economically meaningful. A one-standarddeviation increase in the coverage of credit bureaux reduces the financing gap between small firms and large ones by eight percentage points. Using the same technique, we test if the protection of creditors, measured by effective creditor rights and the type of legal system, reduces the gap between bank credit for large firms and small firms. In common-law countries, which are characterized by a high level of creditor protection, this gap is between 20 and 30 percentage points less than it is in other countries. An improvement in effective creditor rights of one standard deviation reduces the gap between small and large firms by from 9 to 14 percentage points.

The main policy driver for the reduction of the financing gap is an improvement in the protection of creditor rights. Especially for small firms, however, efforts to strengthen creditor rights, which constitutes a titanic task entailing widespread reforms, can be bolstered by the development of information-sharing mechanisms. Our results suggest that the pay-off of this latter type of effort will be greater in countries where creditors' rights are poorly protected. Future theoretical and empirical works would do well to study the complementarity of information sharing and creditor property rights as reflected in our results. Another interesting avenue of research would be to focus on the effect of information sharing on competition and vice versa and on the impact of this interaction on access to credit for SMEs. ${ }^{23}$ As shown in this study, information sharing reduces information asymmetries between lenders and creditors, but this may also reduce banks' ability to appropriate SME rents. This may increase these firms' profits but, as claimed by Petersen and Rajan (1994), it may also make banks less willing to lend to SMEs and therefore reduce their access to credit.

\section{Bibliography}

Barron, J. and M. Staten (2003), "The value of comprehensive credit reports: lessons from the U.S. experience", Credit Reporting Systems and the International Economy, M.J. Miller (ed.), Cambridge, Massachusetts, The MIT Press.

Beck, T. and A. Demirgüç-Kunt (2006), "Small and medium-size enterprises: access to finance as a growth constraint", Journal of Banking and Finance, vol. 30, No. 11, Amsterdam, Elsevier.

Beck, T., A. Demirgüç-Kunt and M. Martínez Pería (2008), "Banking financing for SMEs around the world: drivers, obstacles, business models and lending practices", Policy Research Working Paper, No. 4785, Washington, D.C., World Bank.

Beck, T., A. Demirgüç-Kunt and V. Maksimovic (2005), "Financial and legal constraints to growth: does firm size matter?", The Journal of Finance, vol. 60, No. 1, Wiley.

${ }^{23}$ Brown and Zehnder (2010) analyse the interaction between market power and information sharing. 
(2001), "Financing patterns across the world: the role of institutions", Policy Research Working Paper, No. 2905, Washington, D.C., World Bank.

Beck, T. and others (2006), "The determinants of financing obstacles", Journal of International Money and Finance, vol. 25, No. 6, Amsterdam, Elsevier.

Bennardo, A., M. Pagano and S. Piccolo (2009), "Multiple-bank lending, creditor rights and information sharing", CEPR Discussion Papers, No. 7186, London, Centre for Economic Policy Research.

Brown, M., T. Jappelli and M. Pagano (2009), "Information sharing and credit: firm-level evidence from transition countries", Journal of Financial Intermediation, vol. 18, No. 2, Amsterdam, Elsevier.

Brown, M. and C. Zehnder (2010), "The emergence of information sharing in credit markets", Journal of Financial Intermediation, vol. 19, No. 2, Amsterdam, Elsevier.

Djankov, S., C. McLiesh and A. Shleifer (2007), "Private credit in 129 countries", Journal of Financial Economics, vol. 84, No. 2, Amsterdam, Elsevier.

Feldmann, H. (2013), "Financial system sophistication and unemployment in industrial countries", International Journal of Finance and Economics, vol. 18, No. 4, Wiley.

Freixas, X. and J. Rochet (2008), Microeconomics of Banking, Cambridge, Massachusetts, The MIT Press.

Galindo, A. and A. Micco (2007), "Creditor protection and credit response to shocks", World Bank Economic Review, vol. 21, No. 3, Washington, D.C., World Bank.

(2005), "Bank credit to small and medium-sized enterprises: the role of creditor protection", Working Paper, No. 347, Santiago, Central Bank of Chile.

Galindo, A. and M. Miller (2001), "Can Credit Registries Reduce Credit Constraints? Empirical Evidence on the Role of Credit Registries in Firm's Investment Decisions", Washington, D.C., Inter-American Development Bank, unpublished.

Greene, W. (2004), "Fixed effects and bias due to the incidental parameters problem in the Tobit model", Econometric Reviews, vol. 23, No. 2, Taylor \& Francis.

(2002), "The bias of the fixed effects estimator in nonlinear models", University of New York [online] http:// people.stern.nyu.edu/wgreene/nonlinearfixedeffects.pdf.

IDB (Inter-American Development Bank) (2004), Unlocking Credit: The Quest for Deep and Stable Bank Lending, Washington, D.C.

Jappelli, T. and M. Pagano (2002), "Information sharing, lending and defaults: cross-country evidence", Journal of Banking \& Finance, vol. 26, No. 10, Amsterdam, Elsevier.

Judson, R. and A. Owen (1996), "Estimating Dynamic Panel Data Models: A Practical Guide for Macroeconomists" [online] https://www.federalreserve.gov/pubs/feds/1997/199703/199703pap.pdf.

Kallberg, J. and G. Udell (2003), "Private business information exchange in the United States", Credit Reporting Systems and the International Economy, M.J. Miller (ed.), Cambridge, Massachusetts, The MIT Press.

Kaufmann, D., A. Kraay and M. Mastruzzi (2009), "Governance matters VIII: aggregate and individual governance indicators, 1996-2008", Policy Research Working Paper, № 4978, Washington, D.C., World Bank.

La Porta, R. and others (1998), "Law and finance", Journal of Political Economy, vol. 106, No. 6, Chicago, The University of Chicago Press.

(1997), "Legal determinants of external finance", Journal of Finance, vol. 52, No. 93, Wiley.

Love, I. and N. Mylenko (2003), "Credit reporting and financial constraints", Policy Research Working Paper, No. 3142, Washington, D.C., World Bank.

Moulton, B. (1990), "An illustration of a pitfall in estimating the effects of aggregate variables on micro units", The Review of Economics and Statistics, vol. 72, No. 2, Cambridge, Massachusetts, The MIT Press.

Padilla, A.J. and M. Pagano (1997), "Endogenous communication among lenders and entrepreneural incentives", The Review of Financial Studies, vol. 10, No. 1, Oxford University Press.

Pagano, M. and T. Jappelli (1993), "Information sharing in credit markets", The Journal of Finance, vol. 48, No. 5, Wiley.

Petersen, M. and R. Rajan (1994), "The benefits of lending relationships: evidence from small business data", The Journal of Finance, vol. 49, No. 1, Wiley.

Powell, A. and others (2004), "Improving credit information, bank regulation, and supervision: on the role and design of public credit registries", Policy Research Working Paper, No. 3443, Washington, D.C., World Bank.

Schiantarelli, F. (1996), "Financial constraints and investment: methodological issues and international evidence", Oxford Review of Economic Policy, vol. 12, No. 2.

Schiffer, M. and B. Weder (2001), "Firm size and the business environment: worldwide survey results", Discussion Paper, No. 43, Washington, D.C., International Finance Corporation. 
Stiglitz, J.E. and A. Weiss (1981), "Credit rationing in markets with imperfect information", American Economic Review, vol. 71, No. 3, Nashville, Tennessee, American Economic Association.

Townsend, R. (1979), "Optimal contracts and competitive markets with costly state verification", Journal of Economic Theory, vol. 21, No. 2, Amsterdam, Elsevier.

Warnock, V. and F. Warnock (2008), "Markets and housing finance", Journal of Housing Economics, vol. 17, No. 3, Amsterdam, Elsevier. 


\section{Annex A1}

Table A1.1

Country-level data

\begin{tabular}{|c|c|c|c|c|c|c|c|}
\hline & $\begin{array}{c}\text { Average } \\
\text { share of } \\
\text { investment } \\
\text { financed with } \\
\text { bank credit }\end{array}$ & $\begin{array}{l}\text { Public or } \\
\text { private credit } \\
\text { information } \\
\text { institution } \\
\text { dummy } \\
\end{array}$ & $\begin{array}{l}\text { Public credit } \\
\text { registry } \\
\text { coverage } \\
\text { (per } 1,000)\end{array}$ & $\begin{array}{l}\text { Private credit } \\
\text { bureau } \\
\text { coverage } \\
\text { (per } 1,000)\end{array}$ & $\begin{array}{l}\text { Common } \\
\text { law regime }\end{array}$ & $\begin{array}{l}\text { Effective } \\
\text { creditor } \\
\text { rights index }\end{array}$ & $\begin{array}{l}\text { GDP per } \\
\text { capita, PPP } \\
\text { adjusted } \\
\text { (in logs) }\end{array}$ \\
\hline Albania & 3 & 0 & 0 & 0 & 0 & -0.62 & 8.39 \\
\hline Argentina & 30 & 1 & 149 & 475 & 0 & -0.01 & 9.25 \\
\hline Armenia & 3 & 0 & 0 & 0 & 0 & -0.25 & 7.69 \\
\hline Azerbaijan & 2 & 0 & 0 & 0 & 0 & -0.73 & 7.74 \\
\hline Bangladesh & 13 & 1 & 1 & 0 & 1 & -0.39 & 6.76 \\
\hline Belarus & 5 & 1 & 0 & 0 & 0 & -0.59 & 8.61 \\
\hline Belize & 32 & 0 & 0 & 0 & 1 & 0.16 & 8.56 \\
\hline Bolivia (Plurinational State of) & 24 & 1 & 55 & 134 & 0 & -0.3 & 8.13 \\
\hline Bosnia and Herzegovina & 16 & 0 & 0 & 0 & 0 & -0.61 & 8.47 \\
\hline Brazil & 26 & 1 & 44 & 439 & 0 & -0.06 & 8.97 \\
\hline Bulgaria & 6 & 0 & 0 & 0 & 0 & -0.03 & 8.78 \\
\hline Cambodia & 7 & 0 & 0 & 0 & 0 & -0.46 & 6.85 \\
\hline Canada & 21 & 1 & 0 & 806 & 1 & 0.53 & 10.34 \\
\hline Chile & 38 & 1 & 209 & 227 & 0 & 0.71 & 9.25 \\
\hline China & 9 & 0 & 0 & 0 & 0 & -0.18 & 7.82 \\
\hline Colombia & 29 & 1 & 0 & 187 & 0 & 0 & 8.79 \\
\hline Costa Rica & 18 & 1 & 7 & 55 & 0 & 0.21 & 8.97 \\
\hline Croatia & 19 & 0 & 0 & 0 & 0 & -0.07 & 9.39 \\
\hline Czech Republic & 10 & 0 & 0 & 0 & 0 & 0.53 & 9.71 \\
\hline Dominican Republic & 26 & 1 & 0 & 423 & 0 & -0.17 & 8.6 \\
\hline Ecuador & 15 & 1 & 82 & 0 & 0 & 0 & 8.64 \\
\hline El Salvador & 28 & 1 & 130 & 128 & 0 & -0.32 & 8.53 \\
\hline France & 11 & 1 & 12 & 0 & 0 & 0 & 10.25 \\
\hline Georgia & 7 & 0 & 0 & 0 & 0 & -0.47 & 7.73 \\
\hline Germany & 17 & 1 & 5 & 693 & 0 & 1.55 & 10.3 \\
\hline Guatemala & 27 & 1 & 0 & 35 & 0 & -0.21 & 8.27 \\
\hline Haiti & 11 & 1 & 1 & 0 & 0 & -0.77 & 7.08 \\
\hline Honduras & 20 & 1 & 45 & 0 & 0 & -0.43 & 7.97 \\
\hline Hungary & 15 & 1 & 0 & 15 & 0 & 0.22 & 9.47 \\
\hline India & 33 & 0 & 0 & 0 & 1 & 0.06 & 7.41 \\
\hline Indonesia & 15 & 1 & 3 & 0 & 0 & -0.44 & 7.92 \\
\hline Italy & 42 & 1 & 55 & 416 & 0 & 0.51 & 10.2 \\
\hline Kazakhstan & 7 & 0 & 0 & 0 & 0 & -0.67 & 8.55 \\
\hline Kyrgyzstan & 1 & 0 & 0 & 0 & 0 & -0.63 & 7.29 \\
\hline Lithuania & 8 & 1 & 7 & 0 & 0 & 0.1 & 9.14 \\
\hline Malaysia & 17 & 1 & 105 & 461 & 1 & 0.57 & 9.2 \\
\hline Mexico & 11 & 1 & 0 & 382 & 0 & 0 & 9.35 \\
\hline Moldova (Republic of) & 7 & 0 & 0 & 0 & 0 & -0.2 & 7.31 \\
\hline
\end{tabular}


Table A1.1 (concluded)

\begin{tabular}{|c|c|c|c|c|c|c|c|}
\hline & $\begin{array}{c}\text { Average } \\
\text { share of } \\
\text { investment } \\
\text { financed with } \\
\text { bank credit }\end{array}$ & $\begin{array}{l}\text { Public or } \\
\text { private credit } \\
\text { information } \\
\text { institution } \\
\text { dummy }\end{array}$ & $\begin{array}{l}\text { Public credit } \\
\text { registry } \\
\text { coverage } \\
\text { (per } 1,000)\end{array}$ & $\begin{array}{l}\text { Private credit } \\
\text { bureau } \\
\text { coverage } \\
\text { (per } 1,000)\end{array}$ & $\begin{array}{l}\text { Common } \\
\text { law regime }\end{array}$ & $\begin{array}{l}\text { Effective } \\
\text { creditor } \\
\text { rights index }\end{array}$ & $\begin{array}{l}\text { GDP per } \\
\text { capita, PPP } \\
\text { adjusted } \\
\text { (in logs) }\end{array}$ \\
\hline Nicaragua & 17 & 1 & 50 & 0 & 0 & -0.86 & 7.62 \\
\hline Pakistan & 27 & 1 & 1 & 0 & 1 & -0.17 & 7.55 \\
\hline Panama & 44 & 1 & 0 & 302 & 0 & 0.04 & 8.98 \\
\hline Peru & 25 & 1 & 92 & 185 & 0 & 0 & 8.61 \\
\hline Philippines & 19 & 1 & 0 & 22 & 0 & -0.08 & 7.84 \\
\hline Poland & 13 & 0 & 0 & 0 & 0 & 0.16 & 9.32 \\
\hline Portugal & 13 & 1 & 496 & 24 & 0 & 0.35 & 9.89 \\
\hline Romania & 10 & 0 & 0 & 0 & 0 & -0.13 & 8.85 \\
\hline Russian Federation & 6 & 0 & 0 & 0 & 0 & -0.23 & 9 \\
\hline Singapore & 23 & 0 & 0 & 0 & 1 & 1.71 & 10.46 \\
\hline Slovakia & 11 & 1 & 2 & 0 & 0 & 0.13 & 9.44 \\
\hline Slovenia & 17 & 1 & 14 & 0 & 0 & 0.7 & 9.84 \\
\hline Spain & 20 & 1 & 305 & 48 & 0 & 0.71 & 10.09 \\
\hline Sweden & 19 & 1 & 0 & 489 & 0 & 0.55 & 10.23 \\
\hline Thailand & 34 & 0 & 0 & 0 & 1 & 0.21 & 8.56 \\
\hline Trinidad and Tobago & 37 & 1 & 315 & 0 & 1 & 0.11 & 9.42 \\
\hline Turkey & 20 & 1 & 7 & 0 & 0 & 0.03 & 9.12 \\
\hline United Kingdom & 11 & 1 & 0 & 652 & 1 & 2.14 & 10.25 \\
\hline United States & 18 & 1 & 0 & 810 & 1 & 0.49 & 10.54 \\
\hline Ukraine & 6 & 0 & 0 & 0 & 0 & -0.42 & 8.2 \\
\hline Uruguay & 32 & 1 & 49 & 479 & 0 & 0.32 & 9.14 \\
\hline Uzbekistan & 5 & 0 & 0 & 0 & 0 & -0.59 & 7.37 \\
\hline Venezuela (Bolivarian Republic of) & 15 & 1 & 97 & 0 & 0 & -0.67 & 9.19 \\
\hline
\end{tabular}

Source: Prepared by the authors, on the basis on World Bank, World Business Environment Survey (WBES) and S. Djankov, C. McLiesh and A. Shleifer, "Private credit in 129 countries", Journal of Financial Economics, vol. 84, No. 2, Amsterdam, Elsevier, 2007. 